\title{
International Expansion Strategies of Korean Venture Firms: Entry Mode Choice and Performance
}

\author{
Jay Hyuk Rhee \\ Korea University Business School, Anam-dong, Sungbuk-gu, Seoul, Korea. \\ E-mail: jayrhee@korea.ac.kr
}

This study seeks to advance the state of our theoretical as well as empirical understanding of the determinants of entry mode choice and internationalization performance of new ventures. Based on three leading theoretical perspectives transaction costs, social networks and absorptive capacity — we develop hypotheses focusing on the role of technology-based advantage, the social networks of start-up team members and the absorptive capacity of employees in predicting entry mode choice and new venture internationalization performance. Using data on the internationalization of new Korean ventures, we find evidence that social network and absorptive capacity theories have considerable explanatory power beyond that of transaction cost theory in predicting entry mode choice and the internationalization performance of new ventures.

Asian Business \& Management (2008) 7, 95-114. doi:10.1057/palgrave.abm.9200246

Keywords: entry mode; performance; new venture; transaction costs; social networks; absorptive capacity

\section{Introduction}

As the terms 'accelerated internationalization' (Oviatt and McDougall, 1997; Shrader et al., 2000) and 'born-global' (Hordes et al., 1995; Knight and Cavusgil, 1996; Madsen and Servais, 1997) indicate, many new ventures begin to operate beyond their national borders right after they are 'born' or while they are still 'new'. In doing so, they are likely to face a double-edged sword: the liabilities of newness and foreignness. Operating as a young organization, a new venture faces the liability of newness not shared by established firms with a long operational history (Stinchcombe, 1965); by expanding abroad and operating in unfamiliar environments, it also faces the liability of foreignness not shared by incumbent firms (Hymer, 1976; Johanson and Vahlne, 1977). Thus, knowing how to penetrate and survive in foreign markets is critical for 
new-venture internationalization. Indeed, entry mode choice is one of the most important strategic concerns for firms considering international expansion, because it determines the level of resource commitment.

Not surprisingly, entry mode choice has been a topic of considerable inquiry in the field of international management (Brown et al., 2003), but the issue has usually been discussed and empirically tested within the context of established firms such as multinational corporations, rather than new ventures. With the exception of a few studies to be discussed in detail in the following section, most studies that have investigated the issue of entry mode choice by new ventures have provided only descriptive information on the chosen entry modes. However, investigating entry mode choices in a more systematic way in the context of new ventures can have important theoretical implications, enabling us to investigate the validity of the frameworks in a new setting. Research on entry mode also has important managerial implications, because the selection of an appropriate entry mode can enable new ventures, which usually lack resources, to optimize resource allocations.

Another important issue to investigate is performance, a consequence of international expansion. Facing the double-edged sword, new ventures that expand abroad confront much tougher competition compared with established or incumbent firms. Given that more than half of new ventures are known to fail within their first 4 years (Timmons, 1999), the failure rate can be even higher when competing in unfamiliar environments. Coupled with the recognition that a great deal of attention should be given not only to the decision to start a new venture, but also to its subsequent survival and performance (Sandberg and Hofer, 1987), such a high failure rate makes it necessary to research how effectively new ventures can overcome the doubleedged sword. Thus, investigating the conditions under which new ventures are more or less likely to reap superior performance in international expansion has important managerial and theoretical implications.

Building on these observations, the present study seeks to advance the state of our theoretical as well as empirical understanding of the determinants of entry mode choice and internationalization performance of new ventures. For this purpose, we rely on three leading theoretical perspectives - transaction costs, social networks and absorptive capacity - to investigate these factors in the context of new ventures.

\section{Entry Mode and Performance of New Ventures}

Although the choice of entry mode is a major strategic concern to most firms, its effect on future economic success can be much greater for new ventures than for established firms in the form of multinational corporations (MNCs). In this 
respect, it is surprising that few researchers have investigated entry mode choices in the context of new ventures. The exceptions include Bell (1995), Burgel and Murray (2000), Shrader et al. (2000) and Zahra et al. (2000). Specifically, Bell found that entry mode choice can be affected by the characteristics of the industry in which a firm competes. However, most of the sample in his study relied on either indirect exports or agent/distributors as an entry mode, with very few cases of choosing foreign direct investments (FDIs). Similarly, Burgel and Murray investigated determinants of entry mode choice by analysing export decisions. Shrader et al.,'s primary objective was to investigate how new ventures manage their risk in international operations by balancing the degree of foreign market revenue exposure, host country risk and entry mode commitment. In other words, how a firm chooses one entry mode over another has not been explicitly investigated. Although Zahra et al. (2000) examined diverse entry modes (ie start-ups, acquisitions, licensing agreements and export agreements) as determinants of technological learning and performance, more than two-thirds of the entry modes chosen by the sample were exporting or licensing.

In addition to entry mode choice, the performance consequences of international expansion are important issues for new ventures. The literature has long examined why some new ventures survive while others fail, and it has identified such determinants of new venture survival as the individual characteristics of entrepreneurs (Sandberg and Hofer, 1987; Ostgaard and Birley, 1996; Ensley et al., 2002) and the external environment of new ventures (Robinson, 1998; Bamford et al., 1999; Shepherd et al., 2000).

The present study builds on and extends the literature on the entry mode choice of new ventures and their internationalization performance in three main ways. First, building on previous research, we examine how a new venture's choice of entry mode can be predicted. But unlike most previous research, which has either focused exclusively on export modes or simply compared them with FDIs in general, the present study examines the different options available within FDIs. That is, to further investigate FDI options, we split FDIs into wholly owned modes and joint-venture modes, and investigate the conditions under which new ventures are more or less likely to choose the former over the latter. This approach is a response to a call for the need to make a finer distinction within FDIs and to explicitly distinguish, both theoretically and empirically, between wholly owned and joint-venture modes (Barkema and Vermeulen, 1998).

Second, the present study investigates the performance implications of international expansion by new ventures. Although the current literature embodies a substantial amount of knowledge, another approach towards newventure survival is needed. The exclusive focus on survival may reflect the high early failure rate (Timmons, 1999). As more and more ventures now play a 
major role in the world economy, however, it is necessary to depart from the traditional focus on survival and pay more attention to performance heterogeneity among new ventures.

Finally, we take a theory-based approach toward entry mode choice and the performance of new ventures, using arguments from three leading theories transaction cost, social network and absorptive capacity - to develop hypotheses. Based on those arguments, we develop and test a model that specifies conditions under which firms are more or less likely to choose a certain entry mode and reap superior performance. We acknowledge that constructs derived from other than these three theories may also affect entry mode choice and performance and that it may be important to examine their comparative effects. However, such an examination is outside the scope of this paper. Instead, we attempt to examine in greater depth the theoryderived constructs and clarify their relationships with entry mode choice and performance.

\section{Theories and Hypotheses}

\section{Transaction cost theory}

FDIs, the highest commitment that a firm can make in international business, involve not only the infusion of capital but also the transfer of personnel and technology. Depending on the ownership structure, FDIs can be either wholly owned or joint ventures. When expanding abroad, firms often have to make decisions based on little reliable information. Faced with this lack of information and knowledge about a foreign market, firms may become cautious about committing substantial resources to that market (Johanson and Vahlne, 1977; Erramilli and Rao, 1990). Thus, joint venture modes may be a good choice, permitting new ventures with limited resources to enter more foreign markets, but they may also create threats. According to transaction cost theory, wholly owned modes are preferred over joint-venture modes when firms perceive high transaction costs, including the cost of designing, negotiating, executing and monitoring exchange transactions (Williamson, 1975; Teece, 1983; Hill et al., 1990). Safeguarding their technology from misappropriation is likely to be the most important strategic concern of most firms. Furthermore, the more important the technology as a source of competitive advantage, the greater the incentive to protect it (Hill and Kim, 1988; Tsang, 1997; Meyer, 2001).

For new ventures, which usually lack other resources, including financial and tangible ones, the importance of technology as a source of firm-specific advantage is even greater. In this respect, knowing the best way to choose an appropriate entry mode is critical, as it may decide the extent to which a new 
venture's firm-specific advantages can be protected. The hazards related to technological leakage are most prominent when new ventures choose jointventure modes and their technology-based advantages are exposed to the partners. That is, new ventures that select joint-venture modes may have to deal with potential opportunism problems stemming from free-riding and technology dissemination.

In contrast, new ventures that have complete responsibility and control through wholly owned modes are in a better position to protect their technology-based advantages. The reliance on technology as a source of competitive advantage can also be perceived as a matter of degree rather than a dichotomy. This discussion thus suggests the following hypothesis:

Hypothesis 1: The greater the degree to which their competitive advantages are based on technology, the greater the propensity of new ventures to choose wholly owned modes in their internationalization.

\section{Social network theory}

The importance of social capital, coupled with network characteristics, has led to a growing body of literature seeking to investigate diverse issues related to the causes and consequences of utilizing a network. Defined as 'a set of actors connected by a set of ties' (Borgatti and Foster, 2003), networks may provide actors with the opportunity to establish a set of ties through which they have access to and share information and resources.

'Actors' in the literature on social networks can be broadly classified into two categories: firms and individuals. Many previous studies have taken firms as a level of analysis and investigated how the characteristics of social networks contribute to a firm's technological innovation (Pennings and Harianto, 1992), formation of inter-unit linkage (Tsai, 2001), competitive advantages ( $\mathrm{Lu}$ and Beamish, 2004) and performance (Uzzi and Gillespie, 2002). The importance of knowledge as a source of competitive advantage, coupled with the sticky nature of knowledge, has led many studies to apply social network arguments to MNCs and to investigate how social networks can help MNCs source and transfer knowledge among globally dispersed business units.

While great effort has been devoted to the study of social networks at the firm level, there is less systematic understanding of their contributions to individuals. By using a social network, individuals may be able to access diverse information. The contribution of social networks can be even greater for new ventures, which may have to rely heavily on the experience and knowledge of the start-up team members. As the resource-based view of the firm argues, firm resources that are rare, valuable, non-substitutable and 
imperfectly imitable form the basis for a firm's sustained competitive advantages (Wernerfelt, 1984; Barney, 1991). Thus, human resources in general and top management teams (TMTs) in particular are major determinants of the behaviours and outcomes of their organization.

We expect that start-up teams will have a stronger impact on their firms than TMTs for the following reasons. As 'owners and managers', the start-up team members of a new venture have greater legitimacy in the decision-making process. Thus, their social networks may greatly influence their new venture's strategic outcomes. According to the arguments based on network theory and learning (Birley, 1985; Johanson and Mattsson, 1988; Dubini and Aldrich, 1991; Coviello and Munro, 1995; Barkema et al., 1996), social network can enable actors within a network access to and the opportunity to acquire knowledge from external sources. In other words, network may provide them with an opportunity to establish a set of ties through which they access and learn new knowledge (Burt, 1997). Furthermore, stocks of a firm's employee knowledge are known to positively affect the firm's knowledge creation capability (Smith et al., 2005).

Firms often lack sufficient knowledge about foreign markets, which is an important source of uncertainties in pursuing international expansion. Social networks help mitigate challenges stemming from market uncertainty (Peng and Luo, 2000). As a consequence, under greater uncertainty the top managers' social network becomes more critical, as it can be used to create more stable and reliable relationships with external environments (Luo, 2003). In the context of new ventures, start-up team members who have established larger social networks will feel less risk related to international expansion, and thus will be more likely to choose wholly owned modes. Thus, this discussion suggests the following hypothesis:

Hypothesis 2: The larger the start-up team members' social networks, the greater the propensity of their new ventures to choose wholly owned modes in their internationalization.

\section{Absorptive capacity theory}

When operating in unfamiliar markets, new ventures may have to process much information. According to information-processing theory perspectives (Galbraith 1977; Egelhoff, 1982), the difference between the amount of information required to perform a task and the amount of information possessed by an organization is the relative uncertainty or information to be acquired and processed. To match the information-processing requirement inherent in firm internationalization, employees need to have a corresponding information-processing capacity. Unless they have this capacity, they face 
more ambiguity and feel less confidence in the process of firm internationalization. Given that wholly owned modes involve relatively higher resource commitments and control than joint-venture modes (Hill et al., 1990; Kim and Hwang, 1992), the amount of information required to perform a task would be much higher for the former than the latter. Thus, employees with the required amount of information capacity would be more likely to perceive the selection of a wholly owned operation as a feasible alternative and feel confident in pursuing it as an entry mode. According to absorptive capacity theory (Cohen and Levinthal, 1990), furthermore, such information-processing capability significantly varies across employees, as their current level of knowledge acts as a determining factor in acquiring new knowledge and the information required to pursue certain entry modes. As it takes time to accumulate the knowledge necessary to undertake a certain entry mode, the propensity to select wholly owned operations is not the same even when they are perceived as an appropriate entry mode.

While earlier studies have conceptualized and measured absorptive capacity by R\&D spending (eg Cohen and Levinthal, 1990; Steensma and Corley, 2000; Tsai, 2001), recent literature has encompassed new conceptualizations of absorptive capacity by measuring it at the individual level. Minbaeva et al. (2003) is especially noteworthy. They conceptualize absorptive capacity as comprising 'employees' ability and motivation' and found that knowledge transfer is greatly influenced by absorptive capacity. In the context of international expansion, employees with higher levels of absorptive capacity will be more confident in handling all the tasks required to expand through wholly owned modes. Thus, new ventures whose employees have higher levels of absorptive capacity will view the choice of expansion through wholly owned modes as an attractive and viable strategic option. Thus,

Hypothesis 3: The greater the employees' absorptive capacity, the greater the propensity of their new ventures to choose wholly owned modes in their internationalization.

\section{The Three Perspectives and Performance}

Performance in international operations is reflected by how effectively new ventures overcome 'the liabilities of foreignness', all the additional costs that a firm operating in an overseas market incurs that a local firm would not (Kindleberger, 1969; Hymer, 1976). According to Zaheer (1995), the liabilities of foreignness can arise from firm-specific costs based on a particular company's unfamiliarity with and lack of roots in a foreign environment, which will thus lead foreign firms to have lower profitability than local firms. 
In this respect, the arguments derived from the transaction cost, social network and absorptive capacity theories lead us to the performance-related hypotheses below. As transaction cost theory emphasizes, technology is a major source of competitive advantage for most firms. Indeed, many studies have found a pivotal role for technology in creating and sustaining a firm's competitive advantage (Zahra and Covin, 1994). The importance of technology can be even greater for new ventures that have to deal with the cost of foreignness in addition to that of newness. Technology-based new ventures can penetrate new markets by attracting new customers with the introduction of novel products. They can also create barriers that deter the entry of rivals. They can even become rule-makers by changing, rather than following, the rules of competition in the industry. Not surprisingly, technology is perceived to play a major role in determining the success of new ventures. Indeed, Mudambi and Zahra (2007) found evidence that technological competence significantly improves new ventures' survival in foreign markets. Thus, new ventures that rely more on technology as a source of competitive advantage may effectively overcome the liabilities of foreignness and thus reap superior performance in internationalization.

The arguments based on social network theory also explain performance heterogeneity in new-venture internationalization. As the incremental expansion model argues, firms may have to develop their international operations gradually over time, because they lack sufficient knowledge about foreign market conditions (Johanson and Vahlne, 1977). However, the fact that foreign market knowledge is not distributed uniformly across firms can contribute to sustainable competitive advantages (Wernerfelt, 1984; Barney, 1991). The literature on social network theory has revealed that networks can help firms mitigate uncertainty and promote social learning (Kraatz, 1998), reap superior performance (Rodan and Galunic, 2004) and transfer knowledge (Spencer, 2003). More recently, Zhou et al. (2007) applied the social network approach to the internationalization of small and medium enterprises and demonstrated that the social network perspective can explain the performance consequences of firm internationalization. In a similar vein, the extent to which start-up team members can access knowledge of foreign markets through their diverse social networks may decide how effectively their ventures overcome the inherent disadvantages of operating in unfamiliar foreign markets. Thus, new ventures with start-up members that have extensive social networks may be more effective in discovering and exploiting opportunities than other ventures in the process of expanding abroad (Davidsson and Honig, 2003).

In addition to technology and networks, absorptive capacity can also determine how effectively new ventures deal with the risks inherent in internationalization. Compared with domestic operations, international expansion requires employees to process more complex information and 
utilize new knowledge. Furthermore, the survival of new ventures seems to rely heavily upon their ability to rapidly adjust after processing information inputs from external environments (Nicholls-Nixon et al., 2000). However, as absorptive capacity theory posits (Cohen and Levinthal, 1990), the ability to acquire, assimilate and leverage the new knowledge required for internationalization may vary significantly across firms. Furthermore, as Tsai (2001) empirically confirmed, a business unit with high absorptive capacity is likely to perform well. In the context of new ventures, therefore, employees' level of absorptive capacity can lead to heterogeneity in the international performance of new ventures.

Taken together, the degree to which a new venture relies upon technology as a source of competitive advantage, the magnitude of the social networks possessed by the start-up team members and the level of absorptive capacity of its employees can affect its international performance. This discussion thus suggests the following hypotheses:

Hypothesis 4: The extent to which a firm's competitive advantage is based on technology is positively related to the internationalization performance of new ventures.

Hypothesis 5: The magnitude of the start-up team members' social network is positively related to the internationalization performance of new ventures.

Hypothesis 6: The level of employees' absorptive capacity is positively related to the internationalization performance of new ventures.

\section{Methods}

\section{Sample}

Data collection procedures proceeded in three phases. In the first phase, we reviewed previous research to locate, wherever possible, measures that would appropriately capture the constructs under study, and developed initial Likerttype measurement scales for the study variables. These scales were then pretested and refined by administering the initial survey to small groups. Based on feedback from the initial survey, we made minor modifications for clarity and ultimately produced the measures for the study variables.

In the second phase, a list of Korean venture firms that had international operations through FDIs was assembled using the directory published by the Small and Medium Business Administration. After verifying e-mail addresses, we emailed a questionnaire to 200 randomly selected firms. After three rounds 
of follow-up letters were e-mailed to those who did not respond, 106 questionnaires were returned. Because of missing data on some measures for 11 firms, the final sample size consisted of 95 companies. The informants were managers. We tested for response bias by examining the differences between the early and late respondents in terms of model variables and found no significant differences.

\section{Measurement of Variables}

Whenever possible, we used standard, well-established research instruments with minor changes in wording to adapt them to the context of new venture internationalization.

\section{Dependent variables}

\section{Entry mode}

Respondents were asked to indicate whether their firms implemented wholly owned modes (coded as 1 ) or joint-venture modes (coded as 0 ), as in previous studies (eg Brouthers, 2002).

\section{Performance}

In researching new ventures, measuring performance is one of the biggest challenges due to the lack of traditional financial performance measures that we can apply to them (Cooper, 1993; Bamford et al., 1999). The issues inherent in measuring new-venture performance become even more problematic when measuring it in the context of internationalization (Zahra et al., 2000). Since the respondents in the present study were in a position to provide the best estimation of their firm performance derived from internationalization, we measured firm performance based on their response regarding three financial measures of international performance (sales level, profitability and sales growth) and four non-financial measures (market share, marketing, reputation and market access). These items were adapted from previous studies (Brouthers, 2002). A 5-point Likert-type scale was used, ranging from 1 'does not meet expectations at all' to 5 'meets expectations completely'. Cronbach's alpha for financial and non-financial performance was 0.75 and 0.77 , respectively.

\section{Independent variables}

Competitive advantages based on technology

Because technology is an important determinant of new venture success, we measured the degree to which competitive advantage is based on technology by 
respondents' answers to the question on the importance of technology as a source of competitive advantage for their new ventures. The answers were expressed on a 5-point scale ranging from 'insignificant' to 'critical'.

\section{Start-up team members' social network}

Social networks are usually measured by the number of memberships in certain organizations (Ostgaard and Birley, 1996). Thus, we measured the magnitude of the social networks of start-up team members from answers to the question asking how many social networks had start-up team members relied on to gain access to information necessary for internationalization. The answer was expressed on a 5-point scale ranging from 'none' to 'very much'.

\section{Employees' absorptive capacity}

We measured employees' absorptive capacity from answers to the question asking the level of employees' overall job-related ability (Minbaeva et al., 2003). The answer was expressed on a 5-point scale ranging from 'very low' to 'very high'.

\section{Control variables}

\section{Firm size}

We included firm size as a control variable. Previous research has suggested that entry mode choice and performance may be influenced by firm size (eg Pan et al., 1999). The literature measures a firm's size in three ways, according to sales volume, net assets and number of employees. The use of any one of these can be justified, because they are highly correlated (eg Singh, 1986). In the present study, firm size was measured as the number of employees. Firm age was measured by the number of years a firm had been in existence. Psychic similarity was also included, depending on the respondents' perceptions of psychic distance between their home and host countries, because this may affect entry mode choice and performance (eg Uhlenbruck, 2004). Industry, a dummy variable indicating whether a firm belonged to a service industry (1) or a manufacturing industry (0), was included as a control variable, as in previous studies (eg Kogut and Singh, 1988; Brouthers, 2002).

\section{Results}

\section{Descriptive statistics and correlations}

Table 1 reports the means, standard deviations and correlations for the variables used in the present study. No correlation between the study variables was deemed large enough to raise serious concerns about multicollinearity. 
Table 1 Descriptive statistics and correlations ${ }^{\mathrm{a}}$

\begin{tabular}{lrrrrrrrrrrr}
\hline Variable & Mean & s.d. & 1 & 2 & 3 & 4 & 5 & 6 & 7 & 8 & 9 \\
\hline 1. Entry mode & 0.33 & 0.47 & & & & & & & & \\
2. Financial performance & 3.41 & 1.53 & -0.02 & & & & & & & \\
3. Non-financial performance & 3.23 & 1.37 & 0.16 & 0.77 & & & & & & \\
4. Technology-based advantage & 3.12 & 0.99 & 0.54 & 0.32 & 0.40 & & & & & \\
5. Social network & 3.33 & 1.07 & 0.51 & 0.06 & 0.24 & 0.36 & & & & \\
6. Absorptive capacity & 2.92 & 1.23 & 0.47 & 0.30 & 0.40 & 0.45 & 0.45 & & & \\
7. Industry dummy & 0.44 & 0.50 & 0.01 & 0.16 & 0.16 & 0.15 & -0.03 & -0.10 & & \\
8. Firm age & 5.51 & 3.52 & 0.05 & -0.03 & -0.04 & 0.15 & 0.18 & 0.04 & -0.15 & \\
9. Firm size & 15.59 & 6.60 & 0.11 & -0.03 & -0.05 & 0.12 & 0.12 & -0.01 & -0.12 & 0.19 \\
10. Psychic similarity & 2.97 & 1.09 & 0.25 & 0.37 & 0.39 & 0.42 & 0.27 & 0.29 & 0.01 & 0.19 & -0.07 \\
\hline
\end{tabular}

${ }^{\mathrm{a}} N=5$. Correlations with absolute value greater than 0.20 are significant at the $5 \%$ level.

\section{Hypothesis tests}

The hypotheses related to entry mode choice were tested using a binomial logistic model in which the regression coefficients estimated the impact of the independent variables on a new venture's choice of entry modes. A positive (negative) coefficient meant that the independent variable tended to increase the probability that a new venture would choose wholly owned (joint-venture) modes. A total of five logistic regression models were examined, as shown in Table 2: one model that included only control variables, three models to test each hypothesis derived from the three perspectives and one model that included all the study variables.

Model 1 reports the base model, including only the control variables. As its results show, only psychic similarity was a significant determinant of a firm's selection of the wholly owned mode. Models 2-4 tested the hypotheses by focusing on the effect of the independent variables derived from the perspectives on a firm's entry mode choice. Hypothesis 1 posited that the greater the degree to which their competitive advantages are based on technology, the greater the propensity of new ventures to choose wholly owned modes in their internationalization. The technology-based competitive advantages ( $b=1.515, P<0.001)$ were positively and significantly associated with the probability of choosing wholly owned modes, thus providing support for Hypothesis 1, as shown in model 2.

Hypothesis 2 predicted that the larger the start-up team members' social network, the greater the propensity of their new ventures to choose wholly owned modes in their internationalization. The results in model 3 show that the coefficient for social network was positive and significant $(b=1.382$, $P<0.001$ ), thus providing support for Hypothesis 2 . 
Table 2 Results of binomial logit analyses on entry mode choice

\begin{tabular}{lccccc}
\hline & Model 1 & Model 2 & Model 3 & Model 4 & Model 5 \\
\hline Industry dummy & 0.110 & -0.503 & 0.038 & 0.340 & -0.336 \\
& $(0.468)$ & $(0.572)$ & $(0.546)$ & $(0.530)$ & $(0.673)$ \\
Firm age & -0.013 & -0.041 & -0.089 & -0.001 & -0.074 \\
& $(0.068)$ & $(0.079)$ & $(0.086)$ & $(0.072)$ & $(0.094)$ \\
Firm size & 0.049 & 0.027 & 0.046 & 0.059 & 0.042 \\
& $(0.037)$ & $(0.041)$ & $(0.043)$ & $(0.041)$ & $(0.048)$ \\
Psychic similarity & 0.554 & 0.103 & 0.331 & 0.326 & -0.062 \\
& $(0.227)^{*}$ & $(0.275)$ & $(0.277)$ & $(0.251)$ & $(0.325)$ \\
Technology-based advantage & & 1.515 & & & 1.250 \\
& & $(0.369)^{* * *}$ & & & $(0.422)^{* *}$ \\
Social network & & & 1.382 & & 0.942 \\
& & & $(0.361)^{* * *}$ & & $(0.353)^{* *}$ \\
Absorptive capacity & & & & 0.933 & 0.341 \\
& & & & & \\
-2 Log-likelihood & & & & & \\
chi-sq. (d.f.) & 12.121 & 88.217 & 88.698 & 93.397 & $72.082)$ \\
Cox and Snell $R^{2}$ & $(4.871$ & 31.775 & 31.294 & 26.595 & 47.911 \\
$N$ & 0.080 & $(5)^{* * *}$ & $(5)^{* * *}$ & $(5)^{* * *}$ & $(7)^{* * *}$ \\
& 95 & 95 & 0.281 & 0.244 & 0.396 \\
& & 95 & 95 & 95 \\
\hline
\end{tabular}

Note: $* * * P<0.001,{ }^{* *} P<0.01,{ }^{*} P<0.05,{ }^{\dagger} P<0.10$.

Hypothesis 3, which predicted that the greater the employees' absorptive capacity, the greater the propensity of their new ventures to choose wholly owned modes in their internationalization, was supported, as the coefficients for absorptive capacity $(b=0.933, P<0.001)$ were positive and significant in model 4 . When all study variables were included simultaneously in model 5 , the technology-based competitive advantages and the social network turned out to be still significant.

Table 3 contains the results of the analyses focusing on the relationship of the study variables with firm performance. Hypothesis 4 predicted that the extent to which a firm's competitive advantages based on technology would be positively related to performance. As shown by model 6, the coefficients for technology-based advantages were positive and significant for both financial and non-financial performance at $P<0.01$, thus providing support for Hypothesis 4.

By contrast, the coefficients for the social network of the start-up team members were not significant for any measure of performance. Thus, Hypothesis 5 was not supported, as shown in model 7.

Hypothesis 6 predicted that the level of the employees' absorptive capacity would be positively related to performance. As shown by model 8, the 
Table 3 Results of OLS analyses on firm performance

\begin{tabular}{|c|c|c|c|c|c|c|c|c|}
\hline \multirow[t]{2}{*}{ Variable } & \multicolumn{2}{|c|}{ Model 6} & \multicolumn{2}{|c|}{ Model 7} & \multicolumn{2}{|c|}{ Model 8} & \multicolumn{2}{|c|}{ Model 9} \\
\hline & Financial & Non-financial & Financial & Non-financial & Financial & Non-financial & Financial & Non-financial \\
\hline \multicolumn{9}{|l|}{ Control variables } \\
\hline Industry dummy & 0.093 & 0.092 & 0.149 & 0.148 & $0.188^{*}$ & $0.188^{*}$ & 0.140 & 0.143 \\
\hline Firm age & -0.110 & -0.115 & -0.089 & -0.112 & -0.075 & -0.081 & -0.087 & -0.108 \\
\hline Firm size & 0.015 & -0.025 & 0.046 & -0.004 & 0.066 & 0.026 & 0.043 & -0.004 \\
\hline Psychic similarity & $0.318 * *$ & $0.290 * *$ & $0.413 * * *$ & $0.362 * *$ & $0.353 * *$ & $0.314 * *$ & $0.293 * *$ & $0.249^{*}$ \\
\hline Entry mode & $-0.270^{*}$ & -0.069 & -0.138 & -0.009 & $-0.273^{*}$ & -0.093 & $-0.337^{* *}$ & $-0.197^{\dagger}$ \\
\hline Tech-based advantage & $0.331 * *$ & $0.315 * *$ & & & & & $0.249^{*}$ & $0.225^{*}$ \\
\hline Social network & & & -0.031 & 0.171 & & & -0.064 & 0.077 \\
\hline Absorptive capacity & & & & & $0.345 * *$ & $0.377 * * *$ & $0.306^{* *}$ & $0.306^{* *}$ \\
\hline \multicolumn{9}{|l|}{ Model indices } \\
\hline$R^{2}$ & 0.245 & 0.222 & 0.181 & 0.207 & 0.267 & 0.290 & 0.304 & 0.322 \\
\hline Adjusted $R^{2}$ & 0.193 & 0.169 & 0.126 & 0.153 & 0.217 & 0.242 & 0.239 & 0.259 \\
\hline$F$ & $4.748 * * *$ & $4.197 * *$ & $3.251 * *$ & $3.834 * *$ & $5.343 * * *$ & $5.997 * * *$ & $4.700 * * *$ & $5.097 * * *$ \\
\hline d.f. & \multicolumn{2}{|c|}{6,88} & \multicolumn{2}{|c|}{6,88} & \multicolumn{2}{|c|}{6,88} & \multicolumn{2}{|c|}{8,86} \\
\hline
\end{tabular}


coefficients for absorptive capacity were positive and significant for both financial and non-financial performance at $P<0.01$, thus providing support for Hypothesis 6. Model 9, which included the three variables simultaneously, shows similar results: both technology-based advantage and absorptive capacity were positively related to both measures of performance.

\section{Alternative specification}

The present study also investigated whether entry mode mediates the association of international performance with technology-based advantages, social networks and absorptive capacity. For example, if entry mode does mediate the relationship between technology-based advantage and international performance, a statistically significant variable of technology-based advantage should no longer be significant. But the results lend no support to the argument that entry mode mediates the relationship, because the technology-based advantage was still significant. The coefficients for the social network of start-up team members were not significant, regardless of whether entry mode was included or not. We also found no support for the argument that entry mode mediates the relationship between the absorptive capacity of employees and international performance.

\section{Discussion and conclusions}

As the empirical results of the present study reveal, the entry mode choice of new ventures can be predicted by such traditional frameworks as transaction cost theory, which has been extensively applied to and tested with such established organizations as multinational corporations. This finding has significant implications, because the pattern of entry mode choice by new ventures was well predicted by the traditional framework. However, the present study's results also indicate that including additional perspectives can significantly help us predict a new venture's choice of entry mode. Specifically, two perspectives were considered in the present study. As the literature on entrepreneurship consistently reports, the organizational behaviour and patterns of new ventures cannot be fully understood without considering the characteristics of entrepreneurs and employees.

One interesting and important finding from the present study is that, even though they significantly affect entry mode choice, the social networks of startup team members do not help their ventures reap superior performance. This implies that start-up team characteristics in general, and social networks in particular, should be considered separately when predicting the two important issues of internationalization, entry mode and performance. From a practical 
point of view, the non-significant effect of social networks in predicting firm performance is unsurprising, as many start-up team members may be overconfident, experiencing 'entrepreneurial euphoria' (Cooper et al., 1988). In a broad sense, this result is also consistent with those of previous studies that found little or no correlation between the characteristics of the founding entrepreneurs and new venture performance (eg Sandberg and Hofer, 1987; Ostgaard and Birley, 1996). Based on these results, we may conclude that the characteristics of entrepreneurs as a determinant of performance heterogeneity are not as strong as they might look. These results seem to indicate the need to pay more attention to the types of social networks. In other words, the arguments of strong vs weak ties (Granovetter, 1973; Burt, 1992) can be applicable to new ventures in that, depending on the strength or weakness of the start-up team members' ties, their social networks may be more or less likely to have a positive effect on performance in international expansion. This conclusion is highly speculative and requires additional research.

Another theoretical perspective on which the present study relied was the absorptive capacity of employees. Human resources are the primary source of a firm's competitive advantage, regardless of its age or size. However, we expected that human resources as a determinant of making the right entry mode choice and reaping superior performance would be much more important for new ventures than for large corporations with a long history of operations. The results indicate that the absorptive capacity of employees is not as important as the social networks of start-up team members in determining entry mode. For performance in international expansion, however, absorptive capacity turned out to be the most important predictor. To undertake internationalization, employees usually have to deal with a substantial amount of information. As information-processing theory argues (Galbraith, 1977; Egelhoff, 1982), employees tend to experience a mismatch between the requirements of and the capacity for information processing if they do not possess the required information-processing capacity. Furthermore, employees are likely to experience ambiguity, which is more likely to result in under-utilizing opportunities inherent in internationalization. Thus, the level of absorptive capacity among employees is an important determinant of firm performance in internationalization, as indicated by the present study's results. Taken together, these results indicate that the characteristics of competitive advantage (ie technology) and employees (ie absorptive capacity) can cushion the liabilities of foreignness and positively affect the probability of reaping superior performance.

This study has several limitations. First, its findings are based on a sample limited to new ventures in Korea. Thus, they should not be generalized without further replication in a different context. As implied by institutional theory (DiMaggio and Powell, 1983), the results of the present study might reflect the 
characteristics of institutional pressures and social norms in Korea. Thus, new ventures in other regions of the country or in foreign countries should be surveyed to discover any similarities or differences in patterns of entry mode choice and performance (McGrath et al., 1992). Related to this issue is how to define new ventures, which may vary across countries. In some countries, including Korea, many small- and medium-sized firms are treated as venture firms, given their similar characteristics in several dimensions. Thus, future research might want to pay more attention to operational definitions of new ventures. Second, there is also a need for improved measures of the study variables. For some variables, we had to rely on single-item scales. It is not clear whether this might have biased the results. More elaborate measures of various aspects of new venture internationalization may also warrant future study. Third, as in past transaction-cost-based entry mode and performance studies, we exclusively focused on the choice between wholly owned and jointventure modes. Future research, however, might want to include other entry mode options. Finally, we focused on three key contextual factors that may affect entry mode and internationalization performance. Therefore, another potentially important theoretical extension of the present study would be to investigate other contextual factors.

Because of the limitations mentioned earlier, the present study is only a first step towards a more thorough understanding of the internationalization of new ventures. Despite these limitations, we hope the present findings provide a foundation for more rigorous research on entry mode choice and internationalization performance of new ventures. As the empirical findings of the present study indicate, these entry mode choices and performance can be explained from several theoretical perspectives.

Furthermore, the present study found that social network and absorptive capacity theories have considerable explanatory power beyond that of transaction cost theory. In this respect, additional theoretical perspectives need to be applied to better understand the internationalization of new ventures, and we hope this study serves as a stimulus for further research on this important topic.

\section{Acknowledgements}

We acknowledge the Guest Editor of this special issue of $A B M$ and reviewers for their valuable comments and suggestions, which led to significant improvements to the paper. We acknowledge the financial support from a Korea University Grant.

\section{References}

Bamford, C., Dean, T. and McDougall, P. (1999) 'An examination of the impact of initial founding conditions and decisions upon the performance of new bank start-ups', Journal of Business Venturing 15: 253-277. 
Barkema, H.G., Bell, J.H. and Pennings, J.M. (1996) 'Foreign entry, cultural barriers and learning', Strategic Management Journal 17: 151-166.

Barkema, H.G. and Vermeulen, F. (1998) 'International expansion through start-up or acquisition: a learning perspective', Academy of Management Journal 41(1): 7-26.

Barney, J.B. (1991) 'Firm resources and sustainable competitive advantage', Journal of Management 17: 99-120.

Bell, J. (1995) 'The internationalisation of small computer software firms', European Journal of Marketing 29(8): 60-75.

Birley, S. (1985) 'The role of networks in the entrepreneurial process', Journal of Business Venturing 1: $107-117$.

Borgatti, S.P. and Foster, P.C. (2003) 'The network paradigm in organisational research: a review and typology', Journal of Management 29(6): 991-1013.

Brouthers, K.D. (2002) 'Institutional, cultural and transaction cost influences on entry mode choice and performance', Journal of International Business Studies 33(2): 203-221.

Brown, J., Dev, C. and Zhou, Z. (2003) 'Broadening the foreign market entry mode decision: separating ownership and control', Journal of International Business Studies 34(5): 473-491.

Burgel, O. and Murray, G. (2000) 'The international market entry choices of start-up companies in high-technology industries', Journal of International Marketing 8(2): 33-62.

Burt, R.S. (1992) Structural Hole: The Social Structure of Competition, Cambridge: Harvard University Press.

Burt, R.S. (1997) 'The contingent value of social capital', Administrative Science Quarterly 42(2): 339-365.

Cohen, W. and Levinthal, D. (1990) 'Absorptive capacity: a new perspective on learning and innovation', Administrative Science Quarterly 35(1): 128-152.

Cooper, A. (1993) 'Challenges in predicting new venture performance', Journal of Business Venturing 8(3): 241-253.

Cooper, A., Woo, C. and Dunkelberg, W. (1988) 'Entrepreneurs' perceived chances for success', Journal of Business Venturing 3: 97-108.

Coviello, N.E. and Munro, H.J. (1995) 'Growing the entrepreneurial firm: networking for international market development', European Journal of Marketing 29(7): 49-61.

Davidsson, P. and Honig, B. (2003) 'The role of social and human capital among nascent entrepreneurs', Journal of Business Venturing 18(3): 97-108.

DiMaggio, P. and Powell, W. (1983) 'The iron cage revisited: institutional isomorphism and collective rationality in organisation fields', American Sociological Review 48: 147-160.

Dubini, P. and Aldrich, H. (1991) 'Personal and extended networks are central to the entrepreneurial process', Journal of Business Venturing 6: 306-313.

Egelhoff, W.G. (1982) 'Strategy and structure in multinational corporations: an informationprocessing approach', Administrative Science Quarterly 17: 313-327.

Ensley, M., Pearson, A. and Amason, A. (2002) 'Understanding the dynamics of new venture top management teams: cohesion, conflict and new venture performance', Journal of Business Venturing 17(4): 365-386.

Erramilli, M.K. and Rao, C.P. (1990) 'Choices of foreign market entry modes by service firms: role of market knowledge', Management International Review 30(2): 135-150.

Galbraith, J.R. (1977) Organisational Design, Reading: Addison-Wesley.

Granovetter, M. (1973) 'The strength of weak ties', American Journal of Sociology 78: $1360-1380$.

Hill, C.W., Hwang, P. and Kim, W.C. (1990) 'An eclectic theory of the choice of international entry mode', Strategic Management Journal 11: 117-128.

Hill, C.W. and Kim, W.C. (1988) 'Searching for a dynamic theory of the multinational enterprise: a transaction cost model', Strategic Management Journal 9: 93-104. 
Hordes, M.W, Clancy, A. and Baddaley, J. (1995) 'A primer for global start-ups', Academy of Management Executive 9(2): 7-12.

Hymer, S. (1976) The International Operations of National Firms: A Study of Direct Foreign Investment, Cambridge: MIT.

Johanson, J. and Mattsson, L.G. (1988) 'Internationalisation in Industrial Systems - A Network Approach', in N. Hood and J. E. Vahlne (eds.) Strategies in Global Competition, London: Croom Helm, pp. 287-314.

Johanson, J. and Vahlne, J. (1977) 'The internationalisation process of the firm: a model of knowledge development and increasing foreign market commitments', Journal of International Business Studies 8(1): 23-32.

Kim, W.C. and Hwang, P. (1992) 'Global strategy and multinationals' entry mode choice', Journal of International Business Studies 23(1): 29-53.

Kindleberger, C. (1969) American Business Abroad, New Haven: University Press.

Knight, G.A. and Cavusgil, S.T. (1996) 'The born global firm: a challenge to traditional internationalisation theory', Advances in International Marketing 8: 11-26.

Kogut, B. and Singh, H. (1988) 'The effect of national culture on the choice of entry mode', Journal of International Business Studies 19(3): 411-432.

Kraatz, M. (1998) 'Learning by association? Inter-organisational networks and adaptation to environmental change', Academy of Management Journal 41(6): 621-643.

Lu, J. and Beamish, P. (2004) 'Network development and firm performance: a field study of internationalising Japanese firms', Multinational Business Review 12(3): 41-61.

Luo, Y. (2003) 'Industrial dynamics and managerial networking in an emerging market: the case of China', Strategic Management Journal 24: 1315-1327.

Madsen, T.K. and Servais, P. (1997) 'The internationalisation of Born Globals: an evolutionary process?' International Business Review 6(6): 561-583.

McGrath, R.G., MacMillan, I.C. and Scheinberg, S. (1992) 'Elitists, risk-takers and rugged individualists? An exploratory analysis of cultural differences between entrepreneurs and nonentrepreneurs', Journal of Business Venturing 7: 115-135.

Meyer, K.E. (2001) 'Institutions, transaction costs and entry mode choice in Eastern Europe', Journal of International Business Studies 32(2): 357-367.

Minbaeva, D., Pedersen, T., Björkman, I., Fey, C. and Park, H. (2003) 'MNC knowledge transfer, subsidiary absorptive capacity and HRM', Journal of International Business Studies 34: 586-599.

Mudambi, R. and Zahra, S. (2007) 'The survival of international new ventures', Journal of International Business Studies 38: 333-352.

Nicholls-Nixon, C., Cooper, A. and Woo, C. (2000) 'Strategic experimentation: understanding change and performance in new ventures', Journal of Business Venturing 15: 493-521.

Ostgaard, T.A. and Birley, S. (1996) 'New venture growth and personal networks', Journal of Business Research 36: 37-50.

Oviatt, B.M. and McDougall, P.P. (1997) 'Challenges for internationalisation process theory: the case of international new ventures', Management International Review 37(2): 85-99.

Pan, Y., Li, S. and Tse, D.K. (1999) 'The impact of order and mode of market entry on profitability and market share', Journal of International Business Studies 30(1): 81-104.

Peng, M. and Luo, Y. (2000) 'Managerial ties and firm performance in a transition economy: the nature of a micro-macro link', Academy of Management Journal 43: 486-501.

Pennings, J.M. and Harianto, F. (1992) 'The diffusion of technological innovation in the commercial banking industry', Strategic Management Journal 13(1): 29-46.

Robinson, K. (1998) 'An examination of the influence of industry structure on eight alternative measures of new venture performance for high-potential independent new ventures', Journal of Business Venturing 14: 165-187. 
Rodan, S. and Galunic, C. (2004) 'More than network structure: how knowledge heterogeneity influences managerial performance and innovativeness', Strategic Management Journal 25: 541-562.

Sandberg, W. and Hofer, C. (1987) 'Improving new venture performance: the role of strategy, industry structure and the entrepreneur', Journal of Business Venturing 2: 5-28.

Shepherd, D.A., Ettenson, R. and Crouch, A. (2000) 'New venture strategy and profitability: a venture capitalist's assessment', Journal of Business Venturing 15(5): 449-467.

Shrader, R.C., Oviatt, B.M. and McDougall, P.P. (2000) 'How new ventures exploit trade-offs among international risk factors: lessons for the accelerated internationalisation of the $21 \mathrm{st}$ century', Academy of Management Journal 43(6): 1227-1247.

Singh, J.V. (1986) 'Performance, slack and risk-taking in organisational decision-making', Academy of Management Journal 29(3): 562-585.

Smith, K.G., Collins, C.J. and Clark, K.D. (2005) 'Existing knowledge, knowledge creation capability and the rate of new product introduction in high-technology firms', Academy of Management Journal 48(2): 346-357.

Spencer, J.W. (2003) 'Global gatekeeping, representation and network structure: a longitudinal analysis of regional and global knowledge-diffusion networks', Journal of International Business Studies 34: 428-442.

Steensma, K. and Corley, K. (2000) 'On the performance of technology-sourcing partnerships: the interaction between partner interdependence and technology attributes', Academy of Management Journal 43(6): 1045-1067.

Stinchcombe, A. (1965) 'Social Structure and Organisations', in J.G. March (ed.) Handbook of Organisations, Chicago: Rand McNally, pp. 142-193.

Teece, D.J. (1983) 'Multinational enterprise, international governance and industrial organisation', American Economic Review 75(2): 3-17.

Timmons, J. (1999) New Venture Creation: Entrepreneurship for the 21st Century, Homewood: Irwin.

Tsai, W. (2001) 'Knowledge transfer in intra-organisational networks: effects of network position and absorptive capacity on business unit innovation and performance', Academy of Management Journal 44(5): 996-1004.

Tsang, E. (1997) 'Choice of international technology transfer mode: a resource-based view', Management International Review 37(2): 151-168.

Uhlenbruck, K. (2004) 'Developing acquired foreign subsidiaries: the experience of MNEs in transition economies', Journal of International Business Studies 35: 109-123.

Uzzi, B. and Gillespie, J. (2002) 'Knowledge spill-over in corporate financing networks: embeddedness and the firm's debt performance', Strategic Management Journal 23: 595-618.

Wernerfelt, B. (1984) 'A resource-based view of the firm', Strategic Management Journal 5: 171-180.

Williamson, O.E. (1975) Markets and Hierarchies: Analysis and Antitrust Implications, New York: Free Press.

Zaheer, S. (1995) 'Overcoming the liability of foreignness', Academy of Management Journal 38(2): 341-363.

Zahra, S. and Covin, J. (1994) 'Domestic and international competitive focus, technology strategy and company performance: an empirical analysis', Technology Analysis and Strategic Management 6(1): 39-53.

Zahra, S.A., Ireland, R.D. and Hitt, M.A. (2000) 'International expansion by new venture firms: international diversity, model of market entry, technological learning and performance', Academy of Management Journal 43(5): 925-950.

Zhou, L., Wu, W.-P. and Luo, X. (2007) 'Internationalisation and the performance of Born Global SMEs: the mediating role of social networks', Journal of International Business Studies 38: 673-690. 